\title{
Right Ventricular Endocardium
}

National Cancer Institute

\section{Source}

National Cancer Institute. Right Ventricular Endocardium. NCI Thesaurus. Code C102343.

The innermost layer of endothelial cells and connective tissue that lines the right ventricle. 